\title{
LOOKING FOR PONTIUS PILATE'S FOOTPRINTS NEAR THE WESTERN WALL: RUSSIAN JEWISH TOURISTS IN JERUSALEM
}

\author{
ALEK D. EPSTEIN and NINA G. KHEIMETS
}

Department of Sociology and Anthropology, Hebrew University of Jerusalem, and Department of Sociology and Political Science, Open University of Israel

\begin{abstract}
This study examined trips to Jerusalem by Russian Jewish tourists who visited Israel during late 1998. The research examines the expectations prior to travel, their actual experiences, and how they related to prior expectations. A content analysis was undertaken of tourist memories and reflective diaries. This analysis was supplemented by personal interviews and by participant observations undertaken during the course of Russian-language guided tours of Jerusalem. The research set out to examine tourist expectations and the differences between expectations and reality. Russian Jewish tourists arrive in Israel having left a country in transition. In the present study it is proposed that what has been called the "master narrative" for Russia has been lost and that this combined with the changed status of religion may have led to an intensified search for roots. The self-identification of today's post-Soviet Jewish intelligentsia is made up of a unique combination of Jewish legacy and the heritage of the Grand Russian Culture, which has been created by Jewish writers and artists as well, although its main narrative is a Christian one. They regard Jewish writers and artists as having made a significant contribution to the development of Russian identity. In the present research it is suggested that any tour by a member of the Post-Soviet Jewish intelligentsia to Jerusalem may be viewed as a "double pilgrimage." The first component is as a pilgrimage to King David's capital, the capital of the original and ancient Jewish state. In this context the Western Wall may be viewed as the most sacred place in Jerusalem. The second component is as a pilgrimage to the roots of Christian civilization. In this context the Via Dolorosa, the Garden of Gethsemane, and the Holy Sepulchre may be viewed as key sacred sites in Jerusalem. In practice, however, the landscapes of the Western Wall and the Garden of Gethsemane differ markedly from the expectations that tourists have and incongruity is evident within the dual role as the center of the Judeo-Christian civilization. In contrast to tourists' expectations of Israel as a destination, Jewish history is in fact communicated most cogently at Yad VaShem, established in 1953 as a place to commemorate Jewish Holocaust victims. It is here that Russian Jewish tourists appear to gain an understanding of their roots.
\end{abstract}

$\begin{array}{llllll}\text { Identity Roots } & \text { Russian Jews } & \text { Holy Land } & \text { Jerusalem } & \text { Tourism } & \text { Pilgrimage }\end{array}$


This study examined trips to Jerusalem by Russian Jewish tourists who visited Israel between 1989 and 1999. The research examines tourist perceptions of Jerusalem, comparing expectations prior to travel with the impact of their experiences.

The tourist population being considered shares common characteristics of language, patterns of collective memory, common cultural capital, and political socialization. Russian tourists in Israel arrive having left a country in transition, characterized by a loss of the "master narrative" and a changed status for religion. The search for roots is particularly evident in the case of national minorities within the former Soviet Union such as Germans, Greeks, and Jews. Members of these groups have to decide whether to remain in their post-Soviet countries of residence or to migrate to the relevant country of their ancestors; in the case of most of Russia's Jews, this means Israel.

The self-identification of today's post-Soviet Jewish intelligentsia combines Jewish (mostly Yiddish) legacy and the heritage of what may be described as the "Grand Russian Culture." Although the main narrative of the Grand Russian Culture is Christian, Jewish writers and artists have also contributed. Members of the Russian intelligentsia also have an awareness of the landscapes of Jerusalem through the memorable description included in what is arguably the most famous Russian novel of the 20th century, namely The Master and Margarita by Mikhail Bulgakov (1939/1967). What will appear authentic to tourists familiar with the text? The concept of authenticity in general is socially constructed, and likely to have different connotations for different types of tourist (Cohen, 1988): Russian Jewish tourists are likely to hold coexisting chronological, historical, metaphysical, and cosmological conceptions of Jerusalem drawing upon both the Russian and Jewish cultures. These dimensions interrelate with the visitor's conception of Jerusalem, often forming various paradoxical combinations. As an example of such a paradox, Pontius Pilate might be imagined to be walking under the arches of the Grand Temple.

Israel was a long established and frequented tourist destination by the 19th century and travel to the Holy Land was already popular. The number of tourists visiting Israel after its establishment in 1948 grew slowly at first, from 22,000 in 1949 to about 42,000 in 1957. As a result of the development of air transportation and increased government support tourism grew rapidly from 1957, reaching 290,000 in 1967. After the Six Day War (1967) visitation continued to accelerate with arrivals exceeding 650,000 in 1971 and rising to 2 million in 1997.

Since the establishment of the State of Israel most tourists have come from the US, though the proportion declined from $40 \%$ in 1971 to $21 \%$ in 1997. Tourists from France, Germany, and the United Kingdom usually occupy the second, third, or fourth place. In 1997 420,700 arrivals were recorded from the United States, 198,900 from the United Kingdom, 182,500 from Germany, and 166,700 from France. With the exception of Germany there are significant Jewish communities in these countries, which account for half of Israel's tourist arrivals. Jewish travelers constitute a significant proportion of visitation from the US, the UK, and France, but relatively few German tourists. Tourists from the Commonwealth of Independent States and other countries of the former Soviet Union occupy fifth place in the arrival statistics. It was not until the late 1980s that government barriers were removed and Soviet citizens were able to travel abroad. Since then arrival numbers from the (now former) USSR have been increasing gradually. As outlined in Table 1,

Table 1

Tourist Arrivals From the Former USSR to Israel (Thousands) and as a Proportion of Total Tourist Arrivals in Israel (Percentages)

\begin{tabular}{lcccccccccr}
\hline Year & 1988 & 1989 & 1990 & 1991 & 1992 & 1993 & 1994 & 1995 & 1996 & 1997 \\
\hline $\begin{array}{l}\text { Number of tourists } \\
\%\end{array}$ & 8.8 & 22.3 & 23.0 & 22.3 & 41.8 & 63.3 & 92.9 & 112.7 & 118.0 & 118.5 \\
\hline
\end{tabular}

Source: 1994-1996-according to State of Israel, Central Bureau of Statistics, Tourism, 1996, p. 12; 1997—State of Israel, Central Bureau of Statistics, Tourism and Hotel Services Statistics Quarterly, 26(4), pp. 30-31. 
Table 2

Tourist Entries From the Former USSR by Country of Residence (1994-1996)

\begin{tabular}{lcccc}
\hline Country of Residence & 1994 & 1995 & 1996 & 1997 \\
\hline Russian Federation & 42.9 & 61.6 & 64.9 & 69.7 \\
Ukraine & 13.9 & 17.8 & 19.5 & 21.7 \\
$\begin{array}{l}\text { Other former USSR } \\
\quad \text { European countries }\end{array}$ & 25.9 & 21.9 & 22.5 & 17.5 \\
$\begin{array}{l}\text { Former USSR Asian } \\
\quad \text { countries }\end{array}$ & 10.2 & 11.4 & 11.1 & 9.6 \\
$\quad$ Total & 92.9 & 112.7 & 118.0 & 118.5 \\
\hline
\end{tabular}

Source: 1994-1996 - according to State of Israel, Central Bureau of Statistics, Tourism, 1996, p. 12; 1997-State of Israel, Central Bureau of Statistics, Tourism and Hotel Services Statistics Quarterly, 26(4), p. $30-31$.

arrivals rose from 8800 in 1998 to 22,300 in 1989 , 41,800 in 1993 , and 115,000 in 1995 , remaining at about this level in 1996 and 1997. The proportion of total visitations by former USSR citizens rose from $2.3 \%$ in 1991 to $5.5 \%$ in 1997 (see Tables 2 and 3).

In response to the growth in visitation, a network of travel agencies has evolved offering guided tours in Russian (for a sociological analysis of the guided tour phenomenon see Holloway, 1981; Schmidt, 1972). Five of these agencies include tours to Jerusalem amongst their range of destinations and may be regarded as Jerusalem specialists. These agencies, namely A.B.C.—Marina Vorobieva Tours, M.M.T.Marina Feldman Tours, Metro Club Tours, Tropic Tours, and Jewish Agency Tours, can be divided into two major categories: those that provide services exclusively to a Russian-speaking clientele (e.g., M.M.T.-Marina Vorobieva Tours), and those that also offer guided tours in other languages (e.g., Tropic Tours).
The tourist agencies involved in servicing Russian-speaking clients advertise in Okna (The Windows), a weekly supplement to the most popular Israeli Russian language newspaper, Vesti (News). Four of 48 pages of this supplement are devoted to advertising Russian guided tours. Two of these agencies (namely, A.B.C. and M.M.T.) offer a range of tours concerned with different aspects of Jerusalem's past and present (such as The Mystery of Underground Jerusalem, and Christian Jerusalem), whereas the others provide general tours to the essential sites of interest in the city. This provides tourists with the opportunity to choose between several kinds of tour itinerary. Tours of Jerusalem are offered starting from various points across the country. Coaches bring tourists to Jerusalem from collection points in Haifa, Tel-Aviv, Beer-Sheva, and other towns.

The research reported in this article was conducted during November-December, 1998. During this period 149 Russian guided tours were organized in Jerusalem (see Table 4). The two largest companies incorporating Jerusalem tours were chosen for the purposes of this research, namely A.B.C.-Marina Vorobieva Tours and M.M.T.-Marina Feldman Tours. The two authors participated twice in an observer capacity in each of three tours of various types organized by each company and once in the general tours of each of three other companies. The observers joined a total of 15 groups. During these excursions, the observers examined tourist behavior as it reflects the discrepancy/correspondence between expectations and reality and interviewed willing participants.

Three research methods were used, namely a content analysis of tourist views, an analysis of traveler memoirs and travel diaries, and interviews and participant observation during the tours.

Table 3

Average Duration of Stay (Days) by Country of Residence

\begin{tabular}{lllllllll}
\hline Year & 1990 & 1991 & 1992 & 1993 & 1994 & 1995 & 1996 & 1997 \\
\hline Tourists from the FSU & 28.2 & 31.6 & 35.7 & 32.7 & 30.0 & 29.3 & 28.3 & $25.1^{*}$ \\
Average stay & 21.5 & 21.6 & 18.4 & 17.8 & 17.0 & 16.1 & 15.6 & 15.4 \\
\hline
\end{tabular}

Source: State of Israel, Central Bureau of Statistics, Tourism, 1996, p. 25.

*Tourists from Russia and Ukraine only (78\% of total number of tourists from the former USSR). This data is based on figures assembled from Table 9, Tourism and Hotel Services Statistics Quarterly, 26(4), p. 44 . 
Table 4

Russian-Speaking Guided Tours in Jerusalem in November-December, 1998

A.B.C.-Marina Vorobieva Tours (total number of guided tours in November-December, 1998: 54)

The Mystery of Underground Jerusalem: 14 times (November, 2, 9, 16, 20, 23, 30, December 4, 5, 11, 12, 18, 19, 25, 26).

Jerusalem - the Holy City for Jews, Christians, and Muslims (including Yad Va-Shem museum and a short visit to Bethlehem): 24 times

(November 1, 2, 3, 8, 9, 12, 15, 16, 20, 22, 25, 29, 30, December 1, 4, 7, 11, 15, 18, 21, 23, 26, 29, 30).

Christian Jerusalem, Bethlehem: 16 times (November 3, 7, 14, 21, 23, 28, December 1, 5, 7, 12, 15, 19, 21, 23, 25, 29).

M.M.T.-Marina Feldman Tours (total number of guided tours in November-December, 1998: 32)

Ancient and Modern Jerusalem: 9 times (November 1, 8, 15, 22, 29, December 8, 14, 22, 29)

Christian Jerusalem, Bethlehem: 12 times (November 3, 6, 10, 14, 17, 19, 24, 28, December 5, 12, 19, 26).

Eternal Jerusalem: 11 times (November 4, 7, 11, 14, 18, 25, December 2, 9, 16, 23, 30).

Metro Club Tours (total number of guided tours in November-December, 1998: 33)

Jerusalem: general tour (November 2, 3, 4, 5, 7, 9, 10, 11, 12, 14, 16, 17, 18, 19, 21, 23, 24, 25, 26, 28, 30, December 3, 5, 7, 10, 14, 17, 19, 21, $24,26,28,30)$.

Tropic Tours (total number of guided tours in November-December, 1998: 17)

Jerusalem: general tour (November 3, 7, 10, 11, 17, 21, 24, 28, December 1, 5, 8, 12, 15, 17, 19, 22, 26)

Jewish Agency Special Tours for Jewish Tourists From the Former USSR (total number of guided tours in November-December, 1998: 13) Jerusalem: (November 2, 8, 9, 16, 23, 29, 30, 7, 9, 14, 20, 21, 28).

Total number of Russian-speaking guided tours in Jerusalem in November-December, 1998: 149.

In Search of Roots-Identity and SelfIdentification in a Changing Post-Soviet Society

It is widely accepted that glasnost (freedom of expression, openness) and perestroika (restructuring) have brought radical changes to all spheres of Soviet society, challenging the existing economic, social, and political structures. Glasnost has altered the nature of the Soviet mass media, offering an overwhelming amount of new, critical, and often disturbing information to an eager public. As the process of change has unfolded, it has become evident that the difficulties being faced by Russian people are far more complex than people imagined when the ideas of perestroika and glasnost first took hold. There have been few, if any, examples of a society subjected to successive processes of selfevaluation and self-criticism on the scale experienced by Russia during the last decade.

One way of examining the changing circumstances is to view the previous experience as a "master narrative." In Svetlana Boym's (1994) words, "there is at least one feature of postmodern culture that is particularly relevant to the post-Soviet situation: the loss of the master narrative. Its disappearance could be not just liberating, but also frightening" (p. 224). The loss of a master narrative manifests itself in changing cityscapes and falling monuments.
During the years of perestroika Russia witnessed the spectacle of monuments being man-handled; public sites have also been transformed. The monument of Lenin in Tallin was "strangled"; in Kiev-he was caged and taken off his pedestal until all that remained were his solitary bronze boots as in a Magritte picture. The toppling of the statue of Felix Dzerzhinsky, founder of the KGB, turned into a public celebration. Such iconoclastic destruction of monuments appears to be have been accompanied by a nostalgia for new idols. Various memorials, meaningful to different generations, have sprung up. This phenomenon emerged most conspicuously in 1988, after the creation of a memorial dedicated to Vladimir Vysotsky, a popular Russian bard, poet, and actor. A more potent monument to glasnost is, however, McDonald's. The McDonald's in Moscow seems to be a monument to the Western world in miniature: it contains models of Big Ben and the Eiffel Tower under a brightly painted Californian sky.

Such grotesque but real-life examples demonstrate a crisis in the patterns of social identification in contemporary Russia. As a conveyor of symbols, culture is a means of linking the past, present, and future, a kind of ongoing social heritage. Consisting of innumerable symbols of meaning, it includes beliefs, rituals, art forms, and ceremonies, as well as 
informal cultural practices such as language, stories, and the rituals of daily life. As stated by Alexander and Smith, (1993) "people, groups, and nations understand their progress through time in terms of stories, plots, which have beginnings, middles, and ends, heroes and antiheroes, epiphanies and denouements, dramatic, comic and tragic forms" (p. 156). Each culture provides a lens through which we view the world and interpret our everyday experiences. It determines what we see and understand, as well as what we omit and misconstrue. However, this theoretical framework appears less useful for the analysis of the contemporary Russian situation where culture can no longer serve as a bridge linking the past, present, and future. The post-Soviet, newly independent states are characterized by a weak civil society and by rapidly changing social values. The citizens of Post-Soviet Russia need a lens that is absent in their repertoire of culturally intended interpretations and skills and in their cultural capital if they are to view the world and interpret their everyday experiences.

From the mid-1920s to the mid-1980s, the Soviet press published many articles deploring the revival of "religious superstition." The authors of such articles ranged from small-town atheistic agitprop groups to prominent academics. Such militant atheism was somewhat eclipsed by gestures made towards the Orthodox Church during the 1988 celebration of 1000 years of Russian Christianity. The atheist State returned three famous monasteries to the Church, declared a new religious law, and offered freedom of worship and conscience for practicing believers of the Christian Church and members of other religious groups for the first time in Soviet history. Unexpectedly, a number of Komsomol members were married in church, and arranged baptism for their children. As has been pointed out by Wilson and Bachkatov (1988), "often enough the basis of religious attraction is the beauty of the liturgy, which lay rituals cannot replace; but there is nostalgia too for a little-known past, idealized by young people in search of their roots" (p. 183). There is also a political dimension for various Soviet national minorities amongst whom the search for their roots was strongly influenced by and connected with the demand for political self-determination.

As Boym (1994) sums up, "in the glasnost period the future-oriented ideology of the avant-garde and
Socialist Realism was replaced by a backward glance of commemoration" (pp. 228-229). Preceding generations were held responsible for mistakes and for complacency. The attitudes of youth toward adult authority figures, including their own parents, have been altered by revelations about the past and challenges to the existing order. There was great confusion about what was to be commemorated and what was to be forgotten. It has become increasingly unclear as to what the true Russian history should look like. Should it be presented as the history of the great Russian state, as a suppressed history of the Orthodox Church, or as the history of resistance to Bolshevism? History appeared to be rewritten every day. Streets were renamed with disorienting swiftness, usually returning to their pre-Soviet names, and there was great uncertainty as to which holidays should be celebrated. When it was decided that Leningrad (Petrograd and St. Petersburg in the past) would return "to its original name," there was a debate as to what the original or authentic name of the city really was. This schizophrenia of language, which might be regarded as therapeutic, occurs all the time. Soviet clichés were rejected in favor of an eclectic mix made up of prerevolutionary words, contemporary American business jargon, and the songs from the "tape culture" of the 1960s.

Jews were among the first groups to embrace the opportunity to rethink the past. Gorlizki (1996) has stated that "one issue under Gorbachev that won broad support within the Jewish movement as a whole was remembrance of the Jewish past. Originally conducted in private apartments, meetings organized to this end gradually moved into the open" (p. 445). In 1987 the two largest gatherings of Jews in many years were held in Leningrad and Moscow in commemorating Jewish resistance during the war. A similar meeting the following year was the first to gain official permission, and from then on a steady stream of demonstrations and commemorative meetings was held, museums were opened, and campaigns were established to erect Jewish national monuments. In 1988, the World Jewish Congress and the Soviet Ministry of Culture reached an agreement to establish a Jewish cultural center in Moscow; in 1989, a cultural center opened up at the site of the Moscow Jewish Musical Theatre on Taganka Square. The center was named after Solomon Mikhoels, a famous Jewish actor and producer, executed at 
Stalin's order 40 years previously (see Rapoport, 1990, pp. 80-97; Vaksberg, 1994, pp. 159-182). Gorbachev's confirmation in 1987 that the "Doctors' plot" had been a fabrication gave the most authoritative of signals to a number of personal recollections of the case that appeared during the following years. By late 1989 there were over 200 Jewish clubs and societies in the USSR. A second important measure of the subsequent growth of Jewish cultural life was the appearance by 1990 of over 50 Jewish periodicals across the USSR.

However, the Jewish past was not the only component of cultural heritage of the Russian Jewish intelligentsia. Brym and Ryvkina (1994) have found in their survey that "while there is a widespread desire for a reanimation of Jewish life in Moscow, Kiev and Minsk, it is doubtful whether more than a third of the population wants to become personally involved" (p. 27). They state that:

fewer than a fifth of the Jews in Moscow, Kiev and Minsk have a working knowledge of Hebrew or Yiddish, belong to or participate in a Jewish organization, have a Jewish upbringing, are giving a Jewish upbringing to their children, or celebrate the Sabbath or the High Holy Days. The cultural and organizational infrastructures of the Jewish communities of Moscow, Kiev and Minsk embrace only a small fraction of the Jewish population; specifically, only 27 percent of the respondents feel that they are part of the Jewish community. (pp. 26-27)

Self-identification on the part of the post-Soviet Jewish intelligentsia is made up of a unique combination of Jewish (mostly, Yiddish)—ethnic and cultural, but not religious-legacy and the heritage of the Grand Russian Culture, to which Jewish writers and artists amongst others have made a contribution. The names of famous Russian painters, such as Isaac Levitan, Leon Bakst, and Mark Antokolsky, poets, like Boris Pasternak, Osip Mandelstam, and Joseph Brodsky, and violinists, such as David Oistrakh, Leonid Kogan, and Vladimir Spivakov, occupied a prominent place in the cultural capital of the Russian Jewish intelligentsia. This was not because they were of Jewish origin, but because they were significant figures who have made a contribution to the broader cultural history of Russia. Despite prominent Jewish contributions, the main narrative of this history is Christian.
The search for roots by the Post-Soviet Jewish intelligentsia has two different orientations: Jewish and Christian, each of them being less religious than cultural. These orientations are sometimes antagonistic and sometimes complementary, features likely to influence the thinking of Russian tourists. Almost all tourists

seek escape from established routines, from the constraints of time and place, and the behavioral codes that rule their daily lives. They believe that this change will recharge their mental and physical batteries so that they will be better able to cope with the pressures of their daily commitments. (Boissevain, 1996, p. 4)

Becoming a tourist, however briefly, means shedding part of one's old identity and normal behavior. This involves adopting a new, temporary identity that necessarily incorporates some elements that are the opposite of the habitual personality and behavior (Graburn, 1983). For the post-Soviet Jewish intelligentsia the meaning of a journey to Jerusalem is more important still. The journey itself becomes a kind of a "double pilgrimage." Being Jews, the meaning of Jerusalem has been influenced, on the one hand, by Jewish self-awareness and historic consciousness, and is spelt out in the Prophets and in the Book of Psalms. As creators of and participants in the mainly Christian Russian culture, they also have an awareness of Jerusalem as the place where Jesus lived, preached, died, and was resurrected. There are of course other visitors, notably those who arrive to Israel in order to spend time with friends and relatives. It is, however, likely that such tourists are more concerned with interpersonal contacts than with the historical sights and other places of tourist interest. They may visit Jerusalem as they would visit a European capital city. In the background is the critical issue of whether to remain in post-Soviet Russia or to emigrate to Israel, implying a search for the future as well as their roots. There is a parallel with the way in which 18 th century Germans went to England to contemplate their future, and 20th century radicals went to postrevolutionary Russia and came home to testify. As Adler (1989) has stated, their attitude was "We've seen the future, and it works" (p. 1375). In the present cases it was however the search for roots which was the main expected outcome of the journey. This was evident 
in most conversations between the researchers and the Russian Jewish tourists. Most respondents constructed an image of Jerusalem as a kind of multiple "axis mundi," the center of a humanistic JudeoChristian civilization. In the words of one of the interviewees,

Jerusalem, this ancient city, the Eternal City, where the Bible comes alive, combines the age-old tradition of humanistic culture and the present-day interests of people. It represents both the sacred ideals of faith and the secular, the political plans of a future universal peace; it is an eternal symbol of poetry and the hopes of millions the world over. (Personal communication)

This attitude to Jerusalem is deeply rooted in both the Christian and Jewish traditions.

\section{Constructing an Image of Jerusalem}

In outlining a sociology of international tourism, Cohen (1972) has stated that:

mass tourism as a cultural phenomenon evolves as a result of a very basic change in man's attitude to the world beyond the boundaries of his native habitat. So long as man remains largely ignorant of the existence of other societies, other cultures, he regards his own small world as the cosmos. What lies outside is mysterious and unknown and therefore dangerous and threatening. It can only inspire fear or, at best, indifference, lacking as it does any reality for him.

Jerusalem, the sacred center of three world religions, which has been a mecca for many centuries, represents one of the few places over many centuries that has been visited annually by tens of thousands of people-Christians, Jews, and Moslems. Crowning the Judean hills, this eternal holy city is one of the most attractive tourist areas in the world.

The teaching of different religions, and especially Christian religious teaching, attempts to explain pilgrimage as one of the fundamental ways of expressing the believers' self, in a context of both transcendental and earthly, existential issues. Underpinning this interpretation lies the thesis that human life is nothing but a pilgrimage toward the ultimate goal, which is not an earthly one (Vukonic, 1996). The true home of a Christian-according to the medieval conception-is the heavenly Jerusalem. For generations of Christians the Holy Land in general and Jerusalem in particular were the scenes where the most uniquely momentous events of history have been enacted (Bowman, 1991; Davies, 1972; Werblowsky, 1972/1988). The mysteries of the incarnation and redemption took place here. The divine act of salvation, in spite of its universal-and according to some early Fathers, cosmic-significance, had its local manifestation here. The annunciation, the nativity, Christ's childhood and manhood, his ministry and preaching, the consummation of this ministry in his passion, resurrection, and ascension, the birth of the Church on Pentecost, and the beginnings of the first Christian communityall these took place on definite sites in this particular city and land, regardless of whether the sites associated with these events by later tradition were historically "authentic" or not.

The great epoch of Christian pilgrimage started in the early 4th century. Palestine, as the authentic Holy Land and the privileged scene of the events of both Testaments, became the goal of believers, after the discovery of some important relics. Hostels, lodgings, and inns sprang up along the routes taken by pilgrims. These formed the basis for the future network of hospices and caravansaries that started developing, especially from the 11th century on, in Palestine, Rome, on Alpine passes, near major shrines, in short, wherever pilgrims passed through or came to visit. The Church of the Holy Sepulchre, built in 335, was the first of many grandiose structures founded in Jerusalem. The Church building, damaged by fire in 1833 and by earthquake in 1926, has recently been restored through the joint effort of the three principal custodian churches. For Christians, Jerusalem is the place where Jesus lived, preached, died, and was resurrected. While it is the heavenly rather than the earthly Jerusalem that is emphasized by the Church, places mentioned in the New Testament as the sites of his ministry and passion have drawn pilgrims and devoted worshippers for centuries. When, after the Turkish occupation of Jerusalem, the Pope proclaimed that the "Holy City" had been desecrated, this pronouncement caused one of the largest pilgrimages ever in order to preserve Jerusalem for Christianity. Although no firm evidence exists showing the number of pilgrims, the number was enormous according to travel-diarist John Evely. He was told in Rome that during the 
Year of Jubilee (1600), about 440,000 men and 25,000 women were registered at 18 different pilgrims' hostels of the Holy Trinity in Jerusalem (Vukonic, 1996, p. 119). Some authors estimate that in the period between the 12th and 15th centuries, over $30 \%$ of the population was on a pilgrimage toward one of the 10,000 places of pilgrimage then known and recognized. At the heart of religious teaching is humankind's spiritual need to search for and find true values or "the truth." Such a search is usually called pilgrimage or a journey in search of the sacred (Cohen, 1979; Turner, 1973). A different type of pilgrim reached Palestine for the first time during the 16th century. The main exponents were the modern European scholar and the man of science (Schur, 1992, pp. 59-60).

For centuries, the image of Jerusalem occupied a unique place in Russian culture (Batalov \& Lidov, 1994; Ponomarev, 1877). The Slavs knew the route to the East as early as the 6th and 7th centuries. The first recorded journey was that of Varlaam in 1062. In the following century the abbot Daniel, who walked all the way from Kiev to Jerusalem carrying a large silver lamp for the Church of the Holy Sepulchre, placed his lamp there "in the name of all Russia." The abbot, who visited Palestine in 11041107, saw the sacred sites of Jerusalem through the prism of both the Old and New Testaments. In his famous travel diary Khozhdenie igumena Daniila (Itinerary of Abbot Daniel), he described Isaac's altar as an archetypal Golgotha. The comparison of this diary with later travelogues from the end of the 14th and 15th centuries (those of Agrafeniy, Zosima, the merchant Vasiliy, Varsonofiy, and others) and Vasiliy Pozdniakov's pilgrimage in the 16th century, provides a thought-provoking distinction between the constant elements of the genre and incidental ones, which were mainly related to contemporary ideological attitudes. Whereas the tradition of viewing Jerusalem as the "centre of the world," built of stone and adorned with marble and mosaics, the city that witnessed two cycles of sacred history and absorbed the collective memory of generations became more and more formalized: Agrafeniy (the 1370s) saw Jerusalem as the city of Christian tradition on the ruins of Judean antiquities (see GurvichLishchiner, 1997).

The year 1841 marked the establishment of a permanent Russian presence in Jerusalem. Nikolai
Protasov, the Procurator of the Holy Synod from 1836 until 1855, suggested that an archimandrite and two or three monks should be sent to Jerusalem to found a school for teaching Russian and Greek. The school would supervise the use made of Russian alms and to care for Russian pilgrims. This memorandum quickly gained the approval of Tsar Nikolai I and, in November 1842, the Archimandrite Porfiri Uspenski was appointed as founder of the first permanent Russian mission in Jerusalem (see Bolshakoff, 1942; Hopwood, 1969; Sollogub, 1968, pp. 413-474). For the next 70 years the mission took care of the growing numbers of Russian pilgrims visiting Palestine; among them were the famous Russian writers Nikolai Gogol (visited Jerusalem in 1848), Peter Vyazemsky (visited Jerusalem in Passover, 1851), Vyacheslav Ivanov (visited Jerusalem in 1902), and Ivan Bunin (visited Jerusalem in 1907). Most Russian pilgrims were, however, simple peasants, whose devotion and piety left a deep impression on those who saw them. From the shores of the Baltic, from Siberia, and from the banks of Volga and Dnieper they came, leaning on their wooden staffs; most traveling by boat from Odessa to Jaffa (see Graham, 1913). Often a whole village collected money to send one old man or woman to the Holy Land. They arrived before winter, which made travel in the Mediterranean even more hazardous, celebrated Christmas in Bethlehem, and then stayed in Jerusalem until after Easter. On their route they kissed every holy site. They bought many objects to bring back, often to sell, to their villages: little cakes with the image of the Savior stamped on them, candles, crowns of thorns, and palm branches.

Jews, as well as Christians, are traditionally committed to the material aspect of worship and therefore to pilgrimage (see Freedman, 1972). The central place of pilgrimage for Jews, as for Orthodox Christians, is Jerusalem: "For Zion's sake will I not hold my peace, for Jerusalem's sake will I not rest" (Isaiah 62). According to Jewish tradition, Jerusalem is the city chosen by God, and the selection of this city is part of God's covenant with his people. The meaning of Jerusalem as it subsequently determined Jewish self-understanding and historic consciousness is spelled out in the Prophets and in the Book of Psalms. According to ancient tradition, 3 times a year all male inhabitants have to make a pilgrimage to holy places, especially to Jerusalem. The 
Jewish bond to Jerusalem was never broken; for 3 millennia Jerusalem has been the center of the Jewish faith, retaining its symbolic value. According to this tradition, pilgrimages had to be made to Jerusalem once a year from Palestine, and once in a lifetime for Jews from the diaspora. The focal point of Jewish pilgrimages is the Kotel Maaravi, the surviving "Western Wall" of the Second Temple, better known as the Wailing Wall. According to tradition, the tablets of Moses were built into this wall; the Tomb of King David on Mount Zion; and the ancient cemetery on the Mount of Olives where Jews have been buried for centuries-all these are indelibly etched on Jewish consciousness.

These Jewish motifs occupy a central place in the narratives of elderly Jewish Russian tourists, whose socialization for national consciousness took place before the defeat of the Jewish culture in the USSR. Lipkin, a Russian novelist and poet of Jewish origin, has stated that:

To visit Palestine, as they said those days, I have dreamed since I commenced studying the Bible. This dream has never left me. I have loved Israel, ever since I was a child, so that having received the invitation of the Writers' Union, I decided to go there despite my age and my illness. I am soon eighty years old. When, otherwise, could I do it? To see the great Western Wall, King David's grave, which is three thousand years old.... (cited in Chertok, 1991)

Most elderly Jews living in Russia were born in Jewish townlets (shtetls) in the so-called "Pale of Settlement"- the region that included most territories of Ukraine, Belorussia, Lithuania, Poland, and Bessarabia; Russian Jews were confined to this area by laws of 1795 and 1835 (laws which were repealed after the 1917 revolution). In the beginning of the 20th century, there were 5 million Jews living in the Pale, and only 320,000 outside it. Jewish tradition played a central role both in the community and the private life of most Jews in the Pale, and many $\mathrm{Zi}$ onist leaders, among them Ahad Ha-Am (Asher Ginzburg), Leo Pinsker, David Ben-Gurion, and Chaim Weizmann, were born in this area. Traditional Jewish community life and the education system retained their influence in the former Pale of Settlement until the mid-1930s (see Pinkus, 1988), and it seemed natural that people who spent the formative years of their youth in such circumstances would regard Jerusalem as the City of the "great Western Wall, King David's grave, which is three thousand years old."

Today the typical Russian Jewish tourist is more likely to perceive Jerusalem as the origin of both the Jewish and the Christian cultural traditions. In the words of one respondent, "when the doctors have dragged me out from the other world, I decided to visit Israel, the Holy Land, to see with my own eyes the sacred places of Christianity and the Western Wall." Therefore, the Holy Sepulchre and the Western Wall, the Via Dolorosa, and King David's grave together present what might be called an imago mundi. Eliade (1957) has stated that:

Palestine, Jerusalem and the Temple severally and concurrently represent the image of the universe and the Centre of the World ... A universe comes to birth from its centre; it spreads out from a central point that is, as it were, its navel ... The Centre is precisely the place where a break in plane occurs, where space become sacred, hence preeminently real. A creation implies a superabundance of reality, in other words an irruption of the sacred into the world. (pp. 43-45)

According to this view, Jerusalem is city-cosmos, multiple axis mundi of the Judeo-Christian tradition, the realization and materialization of a transcendent model. This attitude inevitably leads to the image of Jerusalem as a marvelous ancient castle, rather than as an ordinary megalopolis. The reality is rather different. Already in 1853, Arthur Penhryn Stanley, Dean of Westminster, remarked that "Jerusalem is one of the places of which the first impression is not the best." The collision of expectations and reality ultimately leads to unforeseen psychological conflict. Such conflict was reflected in most of the interviews undertaken with the Russian Jewish tourists during the present research.

From the Church of All Nations to the Mount of Olives, From the Western Wall to Yad VaShem

From the water, just as from the underworld, something was approaching me with inevitable might. That was neither a town, nor a continent. That was the Promised Land. Being imbued with this thought, I felt sharp emptiness, as if I were falling into an air pocket. I was looking forward silently. The moment of ecstasy has left, having given way to pure curiosity. ... In single file, like children on 
the walk, the passengers went ashore. This way, routinely, I set foot on the asphalt of the Promised Land. There was an ordinary, modest marine terminal, lacking any architectural extravagances. (Stemler, 1993, pp. 26 \& 31)

In these words Ilya Stemler, a Russian writer of a Jewish origin, described his first impressions of a journey to the Holy Land. He visited Israel in 1991, and for a number of reasons his narrative is typical of the authentic feelings of many Russian Jewish tourists.

The most visible connection between tourism and religion consists of thousands of sacred buildings which tourists chose to visit. "The reason for their interest is increasingly to be found in the cultural content of historical value of the sacred building, rather than its original religious purpose" (Vukonic, 1996, p. 61). It is more than just coincidence that a city like Jerusalem possesses a large number of sacred sites. For Christians the list of such places includes the Holy Sepulchre, Church of the Tomb of Mary, Church of Saint Peter in Gallicantu, Church of the Dormition, Church of All Nations, and the Garden of Gethseman. Sometimes, though, the connection to what has been designated by Karl Jaspers (1953) as the Axial Age of the Christianity is hardly discernible. Stemler's (1993) narration on his first visit to the Garden of Gethsemane can serve as a concrete example of such disappointment:

In a low stone wall we found a gate. Two Arabs were standing in the doorway: a man and a boy. They looked at us neither with animosity nor with curiosity. Actually, they looked at us without any expression. There was a marble plaque near the gate. "Garden of Gethsemane." Is this the Garden of Gethsemane?! The Arabs nodded seriously: that's right, there is no fake. This is the Garden of Gethsemane. You can go in, for free. I crossed the threshold. Damn it [sic]! Indeed, there was a garden. There was a very small garden, to be more exact. Beyond a low metal fence, I could see a flower bed with some trees in it. On the earth, there stretched some thin gummy tubes, from which the water was trickling. That was the famous Israeli invention, the drop irrigation, which became world famed for its efficiency and economy... It was somewhere here, among these trees, that, foreseeing his near death, Jesus had talked to his disciples. It was to here that the guards had brought Jesus for the last trial and crucifixion. But where, where? I was greedily scrutinizing this absolutely unremarkable garden. ... (pp. 253-254)
Russian-born tourists must surely have a different image of Jerusalem. Among the agents of representation of the Holy City one cannot find a more influential source than Mikhail Bulgakov's The Master and Margarita, written between 1929 and 1940, published in 1966-1967, and by now recognized as the greatest Russian novel of the 20th century. In his unique masterpiece Bulgakov combines fable, satanic fantasy, and political satire to create an extraordinary hymn to the strength of love. Suppressed in Russia for more than 25 years, the appearance of Bulgakov's books in the 1960s-1970s became more than just staggering events for the Russian intelligentsia (for further discussion see Proffer, 1984). The fact that the scene of four chapters (chapters 2, Pontius Pilate, 16, The Execution, 25, How the Procurator tried to save Yehudah of Kerioth, and 26, The Burial) of Bulgakov's bestknown book, The Master and Margarita, is set in Jerusalem is especially important for this study. According to the state-mediated laws of "scientific atheism" the Bible was never republished in the USSR over a period of 60 years. Therefore, Bulgakov's novel, which between 1973 and 1990 had been printed in more than 10 million copies, became the major replacement for the Bible as a historical source. Millions of Russian citizens formed their image of the Holy City according to Bulgakov's description. It should be added that one of the bestknown places of popular commemoration of the Moscow intelligentsia is the flat 50 on Sadovaya Street, 10, where Mikhail Bulgakov lived from 1921 to 1924 , and where, according to legend, lived the celebrated character from The Master and Margarita, the devil Woland. The haunted house of Bulgakov was re-inhabited by young people in the 1980s, and its black entrance was covered by new graffiti celebrating the heroes of the great novel. Several tourists told us that arriving in Jerusalem they felt a "deep commitment" to visit the places that have been described in the so-called "historic chapters" in The Master and Margarita. Bulgakov's Jerusalem is the city of marvelous palaces and miraculous fortresses, as one can see from the following quotations:

All present started down the wide marble staircase between two walls of roses which were pouring out their numbing scent. They descended lower and 
lower, toward the palace wall and the gates that led to the large, smoothly paved square, at the end of which could be seen the columns and statues of the Yerushalaim hippodrome. (Bulgakov, 1939/1967, pp. 39-40)

When the Procurator came out from under the colonnade onto the sun-flooded upper level of the garden with its palms, he could see, spread out before him, the entire city of Yerushalayim with its hanging bridges, fortresses, and that utterly indescribable hulk of marble with golden dragon scales instead of a roof-the Temple of Yerushalayim. (p. 33)

The Great Temple is both the sacred and profane center of Bulgakov's Jerusalem. The Russian intelligentsia, whose traditional cultural capital includes the magnificent beauty of the churches and palaces of the Russian "Golden Ring" towns, cannot build a less impressive picture of the city that is likely to be the center of the whole Judeo-Christian macro-cosmos.

The significance of Jerusalem's landscapes, as described by Bulgakov in his novel, became evident during many conversations between the researchers and the respondents. One respondent told us that Bulgakov described the Garden of Gethsemane as "thundered with nightingale song" (Bulgakov, 1939/ 1967 , p. 332), and that, according to this tourist's view, it was a perfect description. It seems that the state of affairs almost obliged the traveler to "reconstruct" the picture the way he did. In case of Stemler (1993), the contrast between what had been expected and what was perceived was so striking that, walking in the Garden of Gethsemane, the traveler simply had no other choice: he had been sure that, as he remarked, he was going to "approach, for the first time in [his] life, the most sacred place on earth." All his essence rebelled against the fact that, visually, he came across nothing more than ordinary trees and stones. The magnitude of the dissonance can be explained not even by the fact that Stemler spent a considerable-for a Russian citizen-amount of money for his journey. It was crucially important that the whole cultural, philosophical, and cosmological picture of the world, at the center of which the image of eternal Jerusalem was placed, was questioned. Ordinary trees and stones fail to represent the cradle of world culture, even if one adds to them "the famous Israeli invention, drop irrigation." Thus it is not a reality that a tourist tends to perceive, but a legend, created with love and passion, as it has been described in the following passage:

I was greedily scrutinizing this seemingly unremarkable garden. But imagination (here it is imagination!) was much richer than reality, and my consciousness was penetrated with a different thought: the Garden of Gethsemane cannot look otherwise. It is simple and unpretentious. This garden is as simple as the life of Jesus. It was only afterwards that people marked this man's footsteps with their pompous constructions, raising monuments to themselves rather than to him. And what about the garden? The Garden remains the garden; it cannot be adorned with pillars... The garden lies adjacent to the Church of All Nations, the arches of which are decorated with the emblems of states that took part in its construction. Colored stainedglass windows depict everything that happened (It is not the teller's imagination any more. "Happened"- the teller has already believed in himself!) nearby, in the Garden of Gethsemane: Yehudah's kisses, putting Jesus under arrest, the burial.... (Stemler, 1993, pp. 255-256).

Edward Bruner (1991) somewhat ironically notes that:

tourist advertising and brochures assert that the Western person who travels to exotic countries will have a trip to remember for a lifetime and will return refreshed and renewed, as a new and different person. The hyperbolic language of tourist discourse offers the tourist nothing less than a total transformation of self. (p. 239)

However, in opposition to the developmental capacities of the tourist subject, who has the possibility of being utterly transformed, nothing whatsoever happens to the native object.

In contrast to the promise of a complete change occurring within the tourist self, in a brief 3-week period, the native self remains unchanged, despite the industrial revolution, colonialism, wars of independence, nationalism, the rise of new nations, economic development, and the entire production of modern technology. Nothing changes the native self, which is frozen in time, immobile, and apparently incapable of learning and changing. (Bruner, 1991, pp. 239-240)

That is also the case of Israel and that is precisely the problem. As it has been stated by Cohen (1974), 
The touristic image of Israel which emerges from the guide books appears to be a stable and quite well institutionalized one. In the guide-books, Israel projects primarily an image of an ancient country, replete with sites and settlements of archaeological, historical and religious significance and scenic beauty; a secondary emphasis is given to the landmarks and achievements of the Zionist settlement of the country. Relatively little emphasis is given to the new settlements, formed after the establishment of the state, to non-Jewish settlements, and to centres of recreation and vacationing. (pp. 38-39)

Moreover, Cohen found that the most important trend in the literature is a gradually growing emphasis upon historical and scenic sites (i.e., an increasing stress upon those attractions which endow the country with its unique historical and religious character). Thus, it seems that the emphasis in the touristic image becomes gradually more and more divergent from the actual developmental trends in the country: while the country becomes rapidly industrialized and modernized, the guide books tend increasingly to emphasize its premodern historical, religious, or scientific characteristics. However, there can be no doubt that the landscapes of Jerusalem have been radically changed.

In $70 \mathrm{AD}$ the Roman legions under Titus conquered Jerusalem and destroyed the Temple. After the failure of the Jewish rebellion led by Bar Kochba (132-135 AD), Jews were forbidden to enter the city, which was renamed Aelia Capitolina and rebuilt along the lines of a Roman city. For the next century and a half, Jerusalem was a small provincial town. This situation changed radically when the Byzantine Emperor Constantine transformed Jerusalem into a Christian center. The Church of the Holy Sepulchre, built in 335, was the first of numerous grandiose structures constructed in the city. Three hundred years later, in 634, Muslim armies invaded the country, and in 638 Caliph Omar captured Jerusalem. During the reign of Abdul Malik, who built the Dome of the Rock (691), Jerusalem briefly became the seat of a caliph. The century-long rule of the Umayyad Dynasty from Damascus was succeeded in 750 by the Abbasids from Baghdad, and with them Jerusalem began to decline once again. In 1099 the Crusaders conquered Jerusalem, massacred its Jewish and Muslim inhabitants, and established the city as the capital of the Crusader Kingdom. Under the
Crusaders, synagogues were destroyed and many mosques were turned into Christian shrines. Crusader rule over Jerusalem ended in 1187, when the city fell to Saladin the Kurd. The Mamluks, a military feudal aristocracy from Egypt, ruled Jerusalem from 1250 until 1517 , when the city was conquered by the Ottoman Turks, whose rule lasted for 4 centuries. Suleiman the Magnificent rebuilt the city walls (1537), constructed the Sultan's Pool, and placed public fountains throughout the city. After his death, the central authorities in Constantinople took little interest in Jerusalem. During the 17th and 18th centuries, Jerusalem sunk to one of its lowest ebb. The history of modern Jerusalem began less than a century and a half ago, with the building of Mishkenot Sha' ananim (1860), the first neighborhood outside the city walls. Ninety years later, the armistice lines drawn at the end of the Israeli War of Independence (1948-1949) divided Jerusalem in two, with Jordan occupying the Old City and areas to the north and south, and Israel retaining the western and southern parts of the city. Jerusalem was reunited only during the Six Days War in 1967. In sum, Jerusalem's history could serve an example of an inherent contrast with something that has been characterized by Bruner (1991) as "frozen in time, immobile, and apparently incapable of changing."

This problem is equally true for Jewish sacred places as with Christian ones. As has already been pointed out, combining self-identification as Jews with self-identification as members of the Russian cultural community, most Russian Jews who visit Israel as tourists simultaneously search for their roots in the Garden of Gethsemane, along the Via Dolorosa, at the Holy Sepulchre and at the Western (Wailing) Wall. Probably the most dramatic tension peaks at the Holy Sepulchre. In fact, tourists, who are used to the luxury of the churches of Moscow, Novgorod, Yaroslavl', and Sergiev Posad, seem to be disappointed by the asceticism of Jerusalem's sacred places. The above description of tourists' perception of the Garden of Gethsemane illustrates this point concerning the sacred places of Christianity. The same problem, however, appears also near the Western Wall, the symbol of Jewish faith and the central object of traditional Jewish pilgrimage.

Stemler (1993) described the characteristic disappointment of Russian Jewish tourists from his first visit to the Western Wall: 
In some minutes, I came down the wall, built from huge trimmed stones, which used to prop up the western edge of the temple mount. This is all that survived the destruction. The Western Wall is the most sacred place for the Jews all over the world. All night there loom men figures. Swaying, with their faces to the Wall, these people pray ecstatically, asking the God for support and forgiveness. Between the stones, where the burrs are making their way, there stick out scraps of paper, the prayers' messages to the God, with the sender's address. Having come to this place for the last time, I, too, could not help asking the God for something. Aside, beyond a fence, women were plaguing the God. A soldier with a gun was sitting nearby. Behind his back, I could see the gold cupola of Omar mosque ... I wonder how the sacred places of Muslims, Christians and Jews became entangled here, wall by wall. As for the Western Wall itself, I did not feel trepidation, to my disappointment. (p. 268)

Stemler tries to explain both to himself and to his readers the reason for such indifference:

Perhaps, the anticipation of the event was too strong. Having imagined goodness knows what, I saw an unprepossessing wall, built up of ancient stones. If one's soul has not been imbued with the essence of Judaism, if one's religious knowledge is less than modest, then the asceticism of a ritual suppresses one's delight. Christianity is quite another matter. The pomposity of buildings, their architecture, the rituals, the splendor of clergymen's clothes, the organ sounds, all these inspire one with trepidation ... At any rate, while I was standing near the Western Wall, my mind accepted my People's history, yet my soul remained deaf to it. And I blamed myself for this deafness. (p. 268)

As has been already stated, people who arrive in Israel expecting catharsis from contact with the most remarkable places in their lives are disappointed by unfeeling trepidation and seeing nothing special besides an "absolutely unremarkable garden." Thus Russian Jewish tourists have no other choice but to look for catharsis elsewhere.

Various theorists of tourism observe that museums, such as the British Museum and the Louvre, are often visited by tourists as part of a checklist of "must-see" attractions. Such "must-sees" confirm that one has truly "been there"; they are the "key symbols which mark the achievement of the tourist" (Graburn, 1977, p. 16). Moreover, "museums act as secular temples, or ancestral places, the focus of which, analogous to the religious relic, is the sacredness of the work of art or the authentic object" (Golden, 1996, p. 224; see also Horne, 1984). However, museums in themselves do not have the "attractivity" to draw a wider tourist audience. They are part of a clustered nuclei or mosaic of attractions, often being places tourists seek out once they get to a destination (Leiper, 1990). Most tourists in their journey through this mosaic of attractions are seeking, according to Graburn (1983, p. 19), "condensed interpretations of the natural and cultural heritage" of the place that they are visiting. Museums, on the whole, can be seen by the tourist to provide one such locus in the mosaic where those "condensed interpretations" can be found.

There are two "must-see" museums in Jerusalem, and they are very different. The first of them, the Israel Museum, stands above the Valley of the Cross, on a hill overlooking the Knesset (Israeli parliament) and the Hebrew University campus in Givat Ram. It is known primarily for its archaeological exhibits and the Shrine of the Book where the Dead Sea Scrolls are stored. Although the museum's collection of fine arts includes important works by such painters as Renoir, Monet, Van Gogh, and Magritte, this gallery, inaugurated as recently as 1965 , cannot compete with such old Museums as the Hermitage in St. Petersburg or the Pushkin Museum of Fine Arts in Moscow. The observations made by most respondents who had visited the Israel Museum emphasized "fine buildings" and "nice air-conditioned halls, where you can see separately any picture that you would like to concentrate your attention on-in comparison with the Hermitage where you cannot see less than three-four pictures, because they has been placed very close one to another." They also remarked upon the "unexpectedly good food in the cafeteria." They did not, however, express any strong impression about the exhibits themselves.

The deepest impressions of some of the respondents were connected with the dramatic story of the discovery of the Dead Sea Scrolls. In 1947 a Bedouin shepherd, pursuing a stray goat into a cave near the shore of the Dead Sea, chanced upon a cache of seven ancient scrolls stored in clay jars. Four of the scrolls were eventually purchased by the Syrian Orthodox Monastery of Saint Mark in the Old City of Jerusalem; the other three were acquired by Professor Eliezer Sukenik of the Hebrew University. Sukenik 
(1889-1953) has been recognized as a distinguished archaeologist. Recognizing that the form of the Hebrew scripts resembled inscriptions from the 2000year-old tombs, Sukenik was the first to realize the enormous significance of the scrolls. The Syrian Orthodox Bishop subsequently smuggled the four scrolls out of the country. Sukenik did not live to see the scrolls returned to Jerusalem, but his son Yigael Yadin (1917-1984) traveled to America in 1955 and, with the aid of New York philanthropist Samuel Gottesman, acquired the scrolls on behalf of the State of Israel. The Dead Sea Scrolls, written on parchment, which include fragments of every book of the Hebrew Bible except the Book of Esther, are by far the oldest known biblical manuscripts; the Isaiah Scroll, for example, is a full 1000 years older than any other extant Hebrew biblical text. More than half of the tourists that were interviewed emphasized their deep astonishment when visiting the Shrine of the Book: they could understand nothing of these Hebrew and Aramaic scrolls, yet they were deeply impressed by the historical evidence that apparently proves the fact of a Jewish presence in Palestine 2000 years ago; they were also influenced by the family story of Eliezer Sukenik and his son, Yigael Yadin. The visit to the Shrine of the Book significantly reinforced the nationalistic selfconsciousness of Russian Jewish tourists in Jerusalem.

This sense reaches its apogee in the second museum. Yad VaShem-literally "a monument and a name" (Isaiah 56:5) - is a place of commemoration and homage to 6 million Jewish victims of the Nazi regime. The 1953 Knesset Law (Law on Commemoration of the Holocaust and Heroism) that established Yad VaShem defined the mandate of this institution in part as follows: to "gather, study and publish the entire testimony concerning Holocaust and heroism and endow the nation with its lesson; to foster an atmosphere of unanimity in memory." The Central Archives of the Holocaust and Heroism house over 50 million documents. Yad VaShem is the most prominent of Holocaust memorials in Israel, in part because of its official standing and central location. Moreover, its close proximity to the central military cemetery on Mount Herzl is especially evocative. In the Avenue for the Righteous Among the Nations, over 500 trees are planted to honor heroic Gentiles who risked their lives to save Jews during the Holo- caust. In the Hall of the Names are placed the "Pages of Testimony," recording over 3 million victims, and commemorative books on the destroyed Jewish communities of Europe. In the Ohel Yizkor (Hall of Remembrance), a low building made of unhewn boulders, visitors find themselves in one large, empty hall, where the names of the 22 largest death camps are engraved on the stone floor, and an eternal flame burns. Daylight comes in through the space between the wall and the roof, which is built in the form of a huge concrete marquee. The overwhelming silence is sometimes broken by the sounds of birds flying in through this space and soon escaping to the daylight again.

The analysis of memorialism of national death in Israel led Handelman and Shamgar-Handelman (1997) to the definition of the entry to Yad VaShem as "a voyage to a foreign land within the Israeli landscape" (p. 109), "a voyage to otherness-not to another Israel, but elsewhere. The monumental, ornamented gate at the border has qualities of a checkpoint. Within the Israeli landscape the voyage to Yad VaShem is one through discontinuity, to a foreign land whose physical border is marked by gentiles, not Jews" (p. 105). The major memorial structures of Yad VaShem are of two kinds, closed and open; the functions of the enclosed structures are most embedded in the commemoration of Holocaust genocide, while many of the open ones point more to the heroic, fighting response. The Hall of Remembrance that was inaugurated in 1961 is perhaps the largest enclosed memorial in the complex. Within the dark hall the dominant feeling is that of the bursting emptiness of absence, contained by massive walls and ceiling, focused on the single flame and the imagery of ash, ephemeral dust. Enclosed as it is, the hall is metaphorized as sacred space, the ashes as sacred ash; every man entering the enclosure is requested to don a skullcap, as he would in a cemetery.

The Children's Memorial (inaugurated in 1987) fills a dark void with a multitude of metaphorical images of light. The cave-like memorial, built into the ground, commemorates the estimated million and a half children who perished in the Holocaust. Inside, the only source of light comes from five memorial candles. Through the use of mirrors, their little flames are multiplied infinitely. Entering from the brightness of the natural landscape, one is abruptly suspended in a pitch-black void punctuated by thou- 
sands of tiny lights receding to infinity, the only sound that of a disembodied voice reciting the names, ages, and countries of the dead children. One gropes blindly for the way through. With time, and the adjustment of retinas to the darkness, the lights become merely reflections, artful representations; and then their presence evokes a terrible anguish of absence. There is indeed nothing - nothingness-behind the artifice except the machinery of artifice, no uplifting revelation, no moralistic liturgy. The sense of loss is overwhelming.

One can compare Stemler's (1993) impressions from the Western Wall with his shock from Yad VaShem memorial:

I am entering the Silence.

The Gates let me in. A colossal rectangle, made up of metallic engraving, depicting barbed wire, human hands and eyes, kabalistic symbols and mourning flowers....

There remained Jerusalem somewhere behind these gates.

With its theatres, symphonic orchestra, universities, Knesset, Old City, prophets' graves, restaurants, synagogues, churches, mosques, central market, museums and with another hundred of its big and small sites of interest. ...

Israel remained behind, with its towns, factories, seas, mountains and desert. ...

The whole World remained behind these Gates. . . . (p. 284)

There exists no other place where the History of Mankind would gather so much Sorrow. Grief, suffering, physical pain, death-everything goes by, leaving Sorrow as the memory of the past. Yad vaShem, "the eternal monument," The National Institute of Holocaust and Heroism, embraces by a metallic hoop two dates: 1933-1945; since it is impossible to embrace the immensity, it is impossible to grasp everything that has happened to the People since the disturbance of the first Temple. These twelve years, 1933-1945, however, are enough to ask the God: "For what fault did you put your People on so severe trial?!"

Yet the question that burned SIX MILLION souls did not reach the God's ears. Because it is implausible that He could hear it and let it be. ... (p. 285)
A Russian Jewish tourist's perception is based not on mystical admiration of any formally significant sacred places, but on primary, direct contemplation of the world; therefore, if a Russian Jewish tourist manages to discover himself in Jerusalem, this happens not near the Western Wall, but in the Yad VaShem museum. It is precisely in Yad VaShem that God, the First Temple, and the history of the People as well as of the whole mankind are remembered.

\section{Between Disillusion and Catharsis}

Since the classical work The Marginal Man by Stonequest in 1937, psychologists have been interested in the numerous psychological consequences of travel and sojourning abroad. The very diversity of approaches, interests, and findings makes it difficult to summarize and classify results and theories in this area. However, it seems that the two most important dimensions by which one could attempt to categorize this diffuse research with its often equivocal findings is, firstly, the length of stay-that is the time spent in the new country - and, secondly, the degree of distress that the stay causes (Furnham, 1984).

Theorists of tourist behavior emphasize the connection between tourism and the concept of selfactualization, or self-realization, which is described as a person's dynamic relationship between the real and the ideal self-concept. Self-realization is, therefore, not a state but a process of decreasing the distance between these two cognitive systems which themselves are subject to continuous change. Satisfying the psychogenic need of self-actualization is the process of lifting the real self to the level of the ideal self (see Gnoth, 1997).

One can find a certain degree of similarity between this point and the situation of forced compliance as a result of counter-attitudinal behavior, which has been described by Festinger (1957) in his theory of cognitive dissonance. One of the main findings of the classic experiment by Festinger and Carlsmith (1959) reflected the incentive effect: the less the incentive for engaging in counter-attitudinal behavior, the greater the resulting attitude change. As has been stated by Linder, Cooper, and Jones (1967), to experience dissonance, a person must believe that he chooses to act voluntarily and is thus responsible for the outcome of the decision. This is exactly the 
situation experienced by Russian Jewish tourists in the Holy City: not only voluntary choice, but the realization of a dream of an approach to the sacred center of Judeo-Christian civilization results in the "absolutely unremarkable" Garden of Gesthemane; thus the conclusion that the Garden of Gethsemane "cannot look otherwise," that "it is simple and unpretentious, as Jesus life was," became a logical and visible display of the acceptance of the unexpected situation despite the dissonance.

In his classic study, MacCannell (1973) conceived of the tourist as an alienated modern, who engages in a serious quest for authentic experiences, in remote, nonmodern places and premodern times. Rather than a superficial consumer of pseudo-events, the tourist is construed as a secular pilgrim, whose quest for authenticity is analogous to the quest of the sacred in simpler, premodern societies. However, as tourists proliferate at a destination, their quest is frustrated through the emergence of a "tourist space" within which the locals "stage authenticity," in that they construe spurious attractions, represented or promoted as "real." The tourists' quest is thus frustrated, since they are unable to penetrate the "fronts" and "false backs" with which they are confronted, and reach into the back, the "real" life at the destination.

The anthropologist Oberg (1960) is credited as the originator of the now popular term "culture shock," although the idea behind the term can be traced back to earlier writers. For Oberg, culture shock is precipitated by the anxiety that results from losing all the familiar signs and symbols of social intercourse. He listed a number of different aspects of culture shock; notably feelings of powerlessness, an inability to cope with the new environment. Oberg's model has been reformulated by Smalley (1963), who has specified four phases of culture shock:

1. fascination with a new culture, yet being faced with various barriers preventing social interaction with host nationals;

2. hostility and frustration with aspects of the new culture, and a possible emphasis on the superiority of the original culture;

3. improvement and adjustment;

4. "acceptance of the different" (Smalley himself called this stage "biculturalism," but surely a better definition could be found) in which the sojourner develops a full understanding of the hosts' cultural norms and traditions.

It was Adrian Furnham (1984) who argued that much of the research in the area of culture shock and sojourner adjustment is relevant to the psychology of tourism. In his own words, "many of the topics of research, such as mental and physical reactions to the new culture, communication difficulties, and individual differences in response to the new place are equally applicable in the case of tourists as of immigrants and sojourners" (p. 54). As it has been pointed by Lickorish and Kershaw (1958), religion is an important factor in creating tradition; therefore, one can implement Smalley's (1963) model to the religiously-oriented Russian Jewish tourists' search of the roots.

The first stage, namely "fascination with a new culture," usually takes place before the journey itself. As a result, tourists view Jerusalem as city-cosmos, multiple axis mundi of Judeo-Christian tradition. This is followed by the expectations of contact with extraordinary sites and a magnificent land.

The second stage, namely "disappointment and frustration with aspects of the new culture," is characterized by the tourist's disillusionment with the unbelievable (for the Russian cultural conscientiousness) asceticism of the most sacred sites of Judaism and Christianity. As has been mentioned above, the Post-Soviet Jewish intelligentsia's tour to Jerusalem is planned as a "double pilgrimage": a pilgrimage to King David's capital, the capital of the first Jewish state (and thus the Western Wall is to be recognized as the most sacred place in Jerusalem) in world history, and a pilgrimage to the roots of the Christian civilization (and thus the Via Dolorosa, Garden of Gethsemane, and the Holy Sepulchre are to be recognized as the most sacred places in Jerusalem). However, the existing landscapes of the Western Wall as well as of the Garden of Gethsemane are not identical to the tourists' original expectations and, what is more important, do not seem appropriate as the center of the Judeo-Christian civilization.

The third stage, "adjustment," takes place mostly in the Shrine of the Book in the Israel Museum and in the Yad VaShem memorial complex. As it has been claimed, in the glasnost period a future-oriented ideology was replaced by a backward glance of com- 
memoration, and Russian Jews were among the first to take it forward. Despite the tourist expectations, in Israel it is precisely in Yad VaShem that the whole history of the Jewish People is brought together.

The fourth stage is twofold. Those who undergo emotional stress at the Shrine of the Book in the Israel Museum and in the Yad VaShem memorial complex are likely to reconstruct their expectations in accordance with this state of affairs and, thus, reach the stage of "acceptance of the different." However, those who do not experience any special emotions at these sites might leave Jerusalem unsatisfied and disappointed.

The touristic image of Israel, as presented in the guide-books, appears to be a highly selective and fragmented, if not a distorted, one. In the promotional literature there is a strong emphasis on uninhabited sites and old towns, rather than the communities in which the life of contemporary Israel flourishes. Hence, the tourist is guided primarily to visit the attractive relics of the past, and the "showpieces" of modern Jewish settlement, and to bypass the more mundane but burning and important problems of contemporary Israel. As is the case in many countries, the Israeli communication media thus contribute to the effort of the tourist establishment to channelize tourists into the circuit of tourist attractions and facilities, and to keep them from facing the realities of life in the destination country. The touristic image of Israel reflects the predominantly Zionist conception of the country-the link between the historical past and the modern Jewish resettlement, with added emphasis on the significant landmarks of historical Christianity, apparently aimed at the non-Jewish tourist (see Cohen, 1974). Cohen's thesis was supported by Katriel's (1993, 1997) analysis of Israeli cultural politics as depicted in pioneer settlement museums. Katriel (1993) pointed out that in these museums "visitors' identification with the pioneers is cultivated dialectically through a distancing from the diaspora Jew and the Arab as cultural others" (p. 128). Having explored the walking tours in the Israeli countryside, Selwyn (1996) came to the conclusion that

the boundaries between the times of Moses, David and the kings, the heroes of Massada and Gamla, the settlers of the first aliya, the great Zionist pioneers of the twenties and thirties, the fighters of the war of Israeli independence are all abolished-effectively giving the impression of a seamless, boundaryless web of time which encompasses the past in the present. But other historical boundaries are by contrast emphasized. Moses and Absalom may seem to belong almost to the present. The Canaanites, Greeks, Persians, Romans, Crusaders, Turks and British all belong to the past and are projected in the tours as if they are separated from the present by almost unbridgeable boundaries. (p. 157)

Visits to Yad VaShem may be regarded as playing a central part in the state-directed guided tours. In the 20th century, the ideology of political Zionism constructed ideas of a Jewish homeland in Palestine as the antithesis of Jewish life in the European diaspora. The new generation of Jews in Palestine, and then in Israel, were to be everything their diasporic counterparts were not. There is a strong consensus among Israeli Jews that the Nazis intended the planned, total extermination of the Jewish people. There is no doubt that with all its complications, the Holocaust is understood as national death. In recent years the existence of the state of Israel is being interpreted increasingly as the answer itself to the Holocaust (Friedlander \& Seligman, 1994). Foreign tourists visiting Israel are taken routinely to Yad VaShem at the beginning of their itinerary. They are guided through the $\mathrm{Mu}-$ seum and place wreaths on the anonymous ashes in the Hall of Remembrance. These visitors first learn of the Holocaust, studying it, as it were, from an Israeli Jewish perspective (Handelman \& Shamgar-Handelman, 1997).

Visits to the Yad VaShem complex in Jerusalem have some parallels with the hall dedicated to the memory of "Jewish Martyrs throughout the Ages" in the Tel-Aviv Beth Hatefutsoth (House of the Diaspora) museum (see Golden, 1996). The dimly lit hall is predominantly black, its focal point an imposing memorial column suspended from the high ceiling. The column is composed of layer upon layer of black caging at the center of which runs a thread of gold light. There is, in addition to the column, a large book entitled Scrolls of Fire. A Nation Fighting for its Life. Fifty-Two Chapters of Jewish Martyrology. The book, prefaced by the words of Menachem Mendel of Kotsk, "There is nothing more whole than a broken Jewish heart," is opened at a new chapter-a poem and a painting-each week 
of the year. In chronological order, each poem describes a separate chapter of Jewish suffering, starting with the destruction of the First Temple in 58 $\mathrm{BC}$ and ending with one adjuring us to remember soldiers and civilians who have died "for the freedom of Israel." On the wall there is a plaque dedicated to the memory of those who died in the Holocaust. The Hall of Commemoration is designed to be central to the other sections. It provides access from the first floor to the next and is visible from all three floors of the exhibition. Throughout the exhibitions visitors are encouraged to remember. The deaths to be remembered are, on the one hand, distinctive and unique to particular historical circumstances as represented in the Scrolls of Fire and in the commemorative plaque. On the other hand, these personal fates are presented as manifestations of the collective destiny of the people as a whole.

An interesting trend emerging in the past few years has been the pilgrimages by Israeli Jews to their or their parents' homelands in Eastern Europe and North Africa. As it has been described by Katriel (1993, 1997), the Israeli pioneer settlements are inscribed in the settlement museums as symbolically potent signs in a culturally compelling imaginative recreation of "roots." They are fictionalized as places we have all come from (or might have, or, indeed, should have). Truly houses of memory, they are inevitably also houses of forgetting. However,

as no memory is complete, however, no forgetfulness is. Indeed, the concomitant emergence of secular pilgrimages of another kind, which are now routinely undertaken by Ashkenazi Jews and their offspring, and which similarly involve the search for concrete traces of a dispossessed family past in the towns of villages of Europe, notably Poland, suggests that this erasure has not been complete, that there are other tales of origin, competing versions of Israeli nostalgia. (Katriel, 1993, p. 130)

The similar process takes place among the Oriental Jews; Levy's (1997) research on tourism and pilgrimage among Moroccan-born Israelis entitled "To Morocco and back" is an analysis of one such voyage, which is in a deep sense a search for identity in the old home country of Morocco. Levy emphasizes that when the group left Israel, these people thought of Morocco as an integral part of their identity, but the trip does not express a return to the past, but emphasizes the "Israeli-ness" of their feelings toward Morocco. Sentiments toward an idealized past, with which the Israelis came to Morocco, gradually dissipated along the way, with the growing awareness that present-day Morocco is not "theirs" anymore. In Morocco they found the roots of their Israeli identity. (Levy, 1997, p. 42)

This conceptual framework can help us to understand the Post-Soviet Jewish intelligentsia's search for roots in Jerusalem. Over a period of several decades the topic of the Holocaust had been strictly banned by Soviet censorship: the murder of 6 million Jews by the Nazi regime had remained taboo. Evgeny Yevtushenko's poem Babiy Yar (published in September 1961) and Anatoliy Kuznetsov's novel of the same name (1966) were the sole published works of Russian literature devoted to the Holocaust; many other books, among them The Black Book, edited by Ilia Ehrenburg and Vasiliy Grossman, were not permitted to be published.

Russian tourists familiar with the opulence of the churches of Moscow, Novgorod, Yaroslavl', and Sergiev Posad seem to be disappointed by the asceticism of Jerusalem's sacred places; the Israel museum gallery, inaugurated less than 35 years ago, cannot compete with such old Museums as the Hermitage in St. Petersburg or the Pushkin Museum of Fine Arts in Moscow; whereas the absence of any commemoration memorial to the Jewish Holocaust in Russia creates and explains the dramatic impression of the Yad VaShem complex.

Since the roles of tourist and pilgrim are often blurred, the borderline between tourism and pilgrimage is difficult to establish (Turner, 1973). Turner and Turner (1978) say explicitly, "the tourist is half pilgrim, if the pilgrim is half tourist" (p. 20). Turner advocates the thesis that pilgrimage entails the movement of people from their everyday world of structured roles and statuses to a sacred center where they enter a world of communitas or antistructure through the ritual celebration of their common and universal humanity. However, the findings of the present research suggest "the desire to [visit] a pure and holy cosmos, as it was in the beginning, when it came fresh from the Creator's hands" (Eliade, 1957, p. 65). This may clash with traveler expectations of what a holy place should look like. The traveler is likely to find a site that would correspond to other elements of those expectations and con- 
sider it a holy one, despite even the fact that such site was founded for purposes different from representing the holy on the earth.

\section{Conclusion}

As the content analysis of Russian travelers' memories and their travel diaries (the most popular of which has been Ilia Stemler's bestseller Look at Your Home, Pilgrim! From the Mount Hermon to Eilat, cited in this article) demonstrates, Jerusalem has always been perceived as a mystical place, the belief being that its actual appearance cannot but fit the spiritual magnificence attributed to it by the monotheists. Following this tradition, the Post-Soviet Jewish intelligentsia's tour to Jerusalem is planned as "double pilgrimage": that to King David's capital, the capital of the first Jewish state in the world history, and that to the roots of the Christian civilization. However, the socialization in the country of origin often acts as an obstacle to assimilating cross-cultural messages at sites that have already been prefigured in a culturally specific tradition. It becomes clear from the interviews that tourists used to the luxury of the churches of Moscow, Novgorod, Yaroslavl', and Sergiev Posad seem to be disappointed by the asceticism of Jerusalem's sacred places. Still, the strong expectations of the experiences in Jerusalem are to be compensated: the pilgrimage to the Holy Land must contribute to the strengthening of the tourist's identity, which is endangered by uncertainty and insecurity prevailing in Russia. Paradoxically, as the conversations with the tourists and participant observation during their tours have shown, it is at the Yad VaShem memorial that this compensation takes place. Because the topic of the Holocaust was strictly banned by Soviet censorship as a taboo subject, it is the absence of any memorial to the Jewish Holocaust in Russia that creates and explains the dramatic impression of the Yad VaShem complex. Thus, despite tourist expectations, in Israel it is in the Yad VaShem memorial, established in 1953 by the Knesset Law, that God, the First Temple, and the whole history of the Jewish People are remembered and brought together.

\section{Acknowledgments}

This study originated from a research project on the Israeli Russian intelligentsia and its cultural elite carried out at the Department of Sociology at the
Hebrew University of Jerusalem by the staff lead by Professor Baruch Kimmerling with the support of Israel Foundations Trustees. We would like to express our sincere gratitude to Professor Victor Azarya and Professor Yaron Ezrahi for their helpful comments on the previous versions of the manuscript. Another version of the paper has been presented at the session on The Persistence of God in Post-Modern Consciousness and Aesthetics (Professor Gerda Elata, chairman) at the 7th Conference of the International Society for the Study of European Ideas (ISSEI), August 14-18, 2000, University of Bergen, Norway.

\section{References}

Adler, J. (1989). Travel as performed art. American Journal of Sociology, 94(6), 1366-1391.

Alexander, J., \& Smith, P. (1993). The discourse of American civil society: A new proposal for cultural studies. Theory and Society, 22, 151-207.

Batalov, A., \& Lidov, A. (1994). Jerusalem in Russian culture. Moscow: Nauka. [in Russian]

Boissevain, J. (Ed.). (1996). Coping with tourists. European reactions to mass tourism. Providence: Berghahn Books.

Bolshakoff, S. (1942). The foreign missions of the Russian Orthodox church. New York: Publisher.

Bowman, G. (1991). Christian ideology and the image of a holy land. The place of Jerusalem pilgrimage in the various Christianities. In J. Eade \& M. Sallnow (Eds.), Contesting the sacred (pp. 98-121). London: Routledge.

Boym, S. (1994). Common places. Mythologies of everyday life in Russia. Cambridge: Harvard University Press.

Bruner, E. (1991). Transformation of self in tourism. Annals of Tourism Research, 18, 238-250.

Brym, R., \& Ryvkina, R. (1994). The Jews of Moscow, Kiev and Minsk: Identity, antisemitism, emigration. London: Macmillan Press.

Bulgakov, M. (1967). The master and Margarita (M. Ginsburg, Trans.). New York: Evergeen. (Original work published 1939)

Chertok, S. (1991, April 9, April 10). Israel is the most exciting impression in my life. Conversation with the Poet S. Lipkin. New Russian Word, p. 6, p. 4.

Cohen, E. (1972). Toward a sociology of international tourism. Social Research, 39(1), 164-182.

Cohen, E. (1974). The touristic image of Israel-an analysis of guide books (Working paper No. 21). Tel-Aviv University, Centre for Urban and Regional Studies.

Cohen, E. (1979). A phenomenology of tourist experiences. Sociology, 13 179-201.

Cohen, E. (1988). Authenticity and commoditization in tourism. Annals of Tourism Research, 15(3), 371-386.

Davies, W. D. (1972). Jerusalem and the land: The Christian tradition. In M. Tanenbaum \& R. Z. Werblowsky (Eds.), The Jerusalem colloquium on religion, peoplehood, nation and land (pp. 115-154). Jerusalem: Hebrew Univer- 
sity-Magnes Press.

Eliade, M. (1957). The sacred and the profane. The nature of religion (W. Trask, Trans.). San Diego: Harcourt Brace Jovanovich.

Festinger, L. (1957). A theory of cognitive dissonance. Stanford: Stanford University Press.

Festinger, L., \& Carlsmith, J. (1959). Cognitive consequences of forced compliance. Journal of Abnormal and Social Psychology, 58, 203-210.

Freedman, W. (1972). The selective guide for the Jewish traveler. New York: Macmillan.

Friedlander, S., \& Seligman, A. (1994). The Israeli memory of the Shoah: On symbols, rituals and ideological polarization. In R. Friedland \& D. Boden (Eds.), Now here: Space, time and modernity (pp. 356-371). Berkeley: University of California Press.

Furnham, A. (1984). Tourism and culture shock. Annals of Tourism Research, 11, 41-57.

Gnoth, J. (1997). Tourism motivation and expectation formation. Annals of Tourism Research, 24(2), 283-304.

Golden, D. (1996). The museum of the Jewish diaspora tells a story. In T. Selwyn (Ed.), The tourist image: Myths and myth making in tourism (pp. 223-250). Chichester: John Wiley \& Sons.

Gorlizki, Y. (1996). The Jews. In G. Smith (Ed.), The nationalities question in the post-Soviet states (pp. 436-461). London: Longman.

Graburn, N. (1977). The museum and the visitor experience. In L. Draper (Ed.), The visitor and the museum (pp. 526). Washington: American Association of Museums.

Graburn, N. (1983). The anthropology of tourism. Annals of Tourism Research, 10, 9-33.

Graham, S. (1913). With the Russian pilgrims to Jerusalem. London: Macmillan.

Gurvich-Lishchiner, S. (1997). Jerusalem in Slavic cultures and Slavic studies. Shvut. Studies in Russian and East European Jewish History and Culture, 5, 202-211.

Handelman, D., \& Shamgar-Handelman, L. (1997). The presence of absence. The memorialism of national death in Israel. In E. Ben-Ari \& Y. Bily (Eds.), Grasping land. Space and place in contemporary Israeli discourse and experience (pp. 85-128). Albany: State University of New York Press.

Holloway, J. (1981). The guided tour: A sociological approach. Annals of Tourism Research, 16(2), 377-402.

Hopwood, D. (1969). The Russian presence in Syria and Palestine. 1843-1914. Church and politics in the Middle East. Oxford: Oxford University Press.

Horne, K. (1984). The great museum: The re-presentation of history. London: Pluto Press.

Jaspers, K. (1953). The origin and goal of history. Yale: Yale University Press.

Katriel, T. (1993). Remaking place: Cultural production in an Israeli pioneer settlement museum. History and Memory, 5(2), 104-135.

Katriel, T. (1997). Performing the past. A study of Israeli settlement museums. Mahwah: Erlbaum.

Leiper, N. (1990). Tourist attraction systems. Annals of Tourism Research, 17, 367-384.
Levy, A. (1997). To Morocco and back. Tourism and pilgrimage among Moroccan-born Israelis. In E. Ben-Ari \& Y. Bily (Eds.), Grasping land. Space and place in contemporary Israeli discourse and experience (pp. 25-46). Albany: State University of New York Press.

Lickorish, L., \& Kershaw, A. (1958). The travel trade. London: Practical Press.

Linder, D., Cooper, J., \& Jones, E. (1967). Decision freedom as a determinant of the role of incentive magnitude in attitude change. Journal of Personality and Social Psychology, 6, 245-254.

MacCannell, D. (1973). Staged authenticity: Arrangements of social Space in tourist settings. American Journal of Sociology, 79(3), 589-603.

Oberg, K. (1960). Culture shock: Adjustment to neo-cultural environments. Practical Anthropology, 7, 177-182.

Pinkus, B. (1988). The Jews of the Soviet Union. Cambridge: Cambridge University Press.

Ponomarev, S. (1877). Jerusalem in Palestine in Russian literature, science and fine arts. St. Petersburg. [in Russian]

Proffer, E. (1984). Bulgakov: Life and work. Ann Arbor: Ardis.

Rapoport, L. (1990). Stalin's war against the Jews. New York: The Free Press.

Schmidt, C. (1972). The guided tour. Urban Life, 7(4), 441467.

Schur, Nathan. (1992). Twenty centuries of Christian pilgrimage to the holy land. Tel-Aviv: Dvir Publishing House.

Selwyn, T. (1996). Atmospheric notes from the fields: Reflections on myth-collecting tours. In T. Selwyn (Ed.), The tourist image: Myths and myth making in tourism (pp. 147-161). Chichester: John Wiley \& Sons.

Smalley, W. (1963). Cultural shock, language shock, and the shock of self-discovery. Practical Anthropology, 10, 4956.

Sollogub, A. (1968). Russian Orthodox Church abroad, 1918-1968. Jerusalem: Russian Ecclesiastical Mission.

Stemler, I. (1993). Look at your home, pilgrim! From the Mount Hermon to Eilat. St. Petersburg: Kometa. [in Russian]

Stonequest, E. (1937). The marginal man. New York: Scribner.

Turner, V. (1973). The centre out there: Pilgrim's goal. History of Religions, 12, 191-230.

Turner, V., \& Turner, E. (1978). Image and pilgrimage in Christian culture: Anthropological perspectives. New York: Columbia University Press.

Vaksberg, A. (1994). Stalin against the Jews (Antonina Bouis, Trans.). New-York: Knopf.

Vukonic, B. (1996). Tourism and religion (Sanja Matesic, Trans.). London: Pergamon.

Werblowsky, R. J. Zwi (1988). The meaning of Jerusalem to Jews, Christians and Muslims. The Charles Strong memorial lecture. Israel University Study Group for Middle Eastern Affairs. (Original work published in 1972)

Wilson, A. \& Bachkatov, N. (1988). Living with glasnost. youth and society in a changing Russia. London: Penguin Books. 